\title{
Stabilization of $\mathrm{Cr}(\mathrm{VI})$ from Fine Ferrochrome Dust using Exfoliated Vermiculite
}

\author{
Delphin Mulange wa Mulange ${ }^{a}$, Andrie Mariana Garbers-Craig ${ }^{b}$
}

a Master's degree student, Department of Materials Science and Metallurgical Engineering, University of Pretoria, Pretoria, 0002, South Africa. delmulange@tuks.co.za

b Associate Professor, Department of Materials Science and Metallurgical Engineering, University of Pretoria, Pretoria, 0002, South Africa. Corresponding author. Tel: +27 12-420-3189, Fax: +27 12-3625304, Andrie.Garbers-Craig@up.ac.za

\section{Introduction}

South Africa is the world's largest producer of both chromite and ferrochrome, and accounts for respectively $\sim 39$ and $\sim 42 \%$ of global chromite and ferrochrome production $[1,2]$. Dust arising from ferrochromium facilities poses a potential threat to the environment, human health and other living organisms due to the presence of $\mathrm{Cr}(\mathrm{VII})$ in the dust [3,4]. Hexavalent chromium is known to be highly soluble in water, mobile, acutely toxic, carcinogenic, clastogenic, teratogenic and mutagenic [5-10].

Worldwide regulatory agencies are responsible for setting regulations to protect health, safety, and the environment, and have listed chromium among the 20 top hazardous substances [11]. In South Africa, all work-related environmental matters fall under the Department of Water Affairs and Forestry which has set a drastic regulation limit of 0.02 $\mathrm{mg} \mathrm{L}^{-1}$ for safe discharge of effluent containing $\mathrm{Cr}(\mathrm{VI})[3,11]$. In order to comply with the limit of $0.02 \mathrm{mg}$ of $\mathrm{Cr}(\mathrm{VI})$ per liter, it is essential for industries to treat their effluents before landfill. Therefore, several treatment technologies including chemical reduction and precipitation, adsorption, ion exchange, electrokinetics, physical separation, and bioremediation have been explored for removing heavy metals from solution [1,5-7,11]. However, most of these processes have considerable disadvantages, such as incomplete metal removal, expensive equipment that are required, regular monitoring, and high energy costs $[12,13]$. 
Adsorption emerges as one of the most versatile, low cost and effective methods for removing heavy metals from aqueous solutions [13]. Several researchers demonstrated that clay minerals exhibit a great propensity for adsorbing heavy metals such as chromium, lead, nickel, zinc, copper, and cadmium from aqueous solutions [12-16]. Clay minerals have therefore been widely used in water treatment for decades. Several studies have examined the potential use of vermiculite, a 2:1 layered clay mineral, as ion exchanger for hazardous cations $[8,12,17]$. Since vermiculite is widely available in South Africa, where the largest mines in the world are located, it was decided to examine the potential use of exfoliated South African vermiculite to stabilize $\mathrm{Cr}(\mathrm{VI})$ from fine ferrochrome dust in aqueous solution. Since this study was the first step in evaluating the potential of using exfoliated vermiculite as an adsorbent for $\mathrm{Cr}(\mathrm{VI})$ from ferrochrome dust, test work was performed under controlled batch conditions.

\section{Experimental}

\subsection{Materials and sample preparation}

The fine ferrochrome dust (FCD) used in the present study was collected from the baghouse filter system at Xstrata Lydenburg Works plant, Mpumalanga, South Africa (Table 1). The ferrochrome dust sample was prepared as follows: $10 \mathrm{~kg}$ of received FCD was screened through a $1000 \mu \mathrm{m}$ sieve, and dried in an electric oven at $104 \pm 2^{\circ} \mathrm{C}$ for $24 \mathrm{~h}$. Representative subsamples from the dry FCD were obtained through splitting, after which these subsamples were kept at room temperature in a closed container until it was used in the experiments.

Three vermiculite samples mined at Palabora Mining Company, Limpopo, South Africa, and labeled VER1, VER2 and VER3 were selected for the present work (Table 1). The three samples correspond to an exfoliated commercial grade, and were supplied by Vesuvius South Africa (VER1) and Mandoval Vermiculite (Pty) Ltd South Africa (VER2 and VER3). All the test work was done using VER1, except when the influence of phase chemistry of the vermiculite on the degree of $\mathrm{Cr}(\mathrm{VI})$ removal was examined. During this specific investigation all three vermiculite samples (VER1, VER2 and VER3) were used. 
The exfoliated vermiculite samples were ground and screened into different size fractions. The $<75 \mu \mathrm{m}$ size fraction was subsequently utilized in all test work, as the highest $\mathrm{Cr}(\mathrm{VI})$ removal efficiency was achieved with this size fraction [18].

All chemicals used were of analytical reagent grade and were purchased from Merck. The stock solution containing $100 \mathrm{mg} \mathrm{L}^{-1}$ of $\mathrm{Cr}(\mathrm{VI})$ was prepared by dissolving $0.2829 \mathrm{~g}$ of $\mathrm{AR}$ grade $\mathrm{K}_{2} \mathrm{Cr}_{2} \mathrm{O}_{7}$ in $1000 \mathrm{~mL}$ of distilled water. The required standard solutions were obtained by diluting the stock solution. Distilled water was used in all experiments. The $\mathrm{pH}$ of the solution was adjusted with $0.1 \mathrm{M} \mathrm{HCl}$ and $0.1 \mathrm{M} \mathrm{NaOH}$ solutions.

Table 1. Physico-chemical properties of FCD and exfoliated vermiculite samples.

\begin{tabular}{llllr}
\hline Oxides & FCD & VER1 & VER2 & VER3 \\
\hline Specific surface area $\left(\mathrm{m}^{2} / \mathrm{g}\right)$ & 3.32 & 7.62 & & \\
Bulk density $\left(\mathrm{g} / \mathrm{cm}^{3}\right)$ & 2.11 & 0.17 & & \\
Water soluble fraction $(\mathrm{wt} \%)$ & 0.30 & 1.46 & & \\
$\mathrm{pH}$ (in distilled water) & 8.54 & 9.31 & & \\
$\mathrm{CEC}$ (meq/100g) & - & 132.38 & & 39.30 \\
$\mathrm{SiO}_{2}$ & 19.58 & 40.94 & 39.90 & 8.00 \\
$\mathrm{Al}_{2} \mathrm{O}_{3}$ & 11.52 & 9.78 & 8.45 & 7.78 \\
$\mathrm{Fe}_{2} \mathrm{O}_{3}$ & 15.30 & 8.79 & 8.55 & 0.93 \\
$\mathrm{TiO}_{2}$ & 0.44 & 1.10 & 0.99 & 23.90 \\
$\mathrm{MgO}_{\mathrm{CaO}}$ & 8.93 & 23.56 & 24.70 & 4.10 \\
$\mathrm{Na} \mathrm{N}_{2} \mathrm{O}$ & 2.35 & 3.89 & 3.72 & 0.05 \\
$\mathrm{~K}_{2} \mathrm{O}$ & 0.01 & 0.01 & 0.07 & 4.70 \\
$\mathrm{MnO}$ & 1.00 & 4.83 & 5.12 & 0.06 \\
$\mathrm{P}_{2} \mathrm{O}_{5}$ & 0.26 & 0.07 & 0.06 & 0.64 \\
$\mathrm{Cr} \mathrm{O}_{3}$ & 0.04 & 1.35 & 0.65 & 0.03 \\
$\mathrm{NiO}$ & 20.40 & 0.04 & 0.04 & 0.02 \\
$\mathrm{~V}_{2} \mathrm{O}_{5}$ & 0.10 & 0.02 & 0.03 & 0.01 \\
$\mathrm{ZnO}$ & 0.16 & 0.03 & 0.01 & 0.01 \\
$\mathrm{Ba}$ & 3.95 & 0.01 & 0.01 & 0.05 \\
$\mathrm{LOI}$ & 0.01 & 0.05 & 0.05 & 10.20 \\
\hline Total & 14.29 & 5.19 & 7.97 & 99.78 \\
\hline & 98.34 & 99.66 & 100.32 &
\end{tabular}




\subsection{Instruments and analytical methods}

The bulk densities as well as the $\mathrm{pH}$ of the dust and VER1 vermiculite were determined using the ASTM D 5057-90 [19] and ASTM D 4980-89 methods [20], respectively. The water soluble fraction was determined by the standard method of soil water content measurements [21]. The specific surface areas were measured with the $\mathrm{N}_{2}$ Brunauer-Emmett-Teller (BET) method, using a NOVA 1000e Surface area and Pore Size Analyzer. A Mettler Toledo FG2 digital microprocessor based $\mathrm{pH}$ meter was used for $\mathrm{pH}$ measurements. Three standard buffer solutions at $\mathrm{pH}$ 4.0, 7.0 and 10.0 were employed for calibration. The solutions were shaken with a LABCON MSH10 thermostated magnetic shaker.

The chemical compositions of the FCD and vermiculite samples were determined using XRF analysis. The samples were prepared for XRD analysis using a back loading preparation method. XRD analysis was performed using a PANalytical X'Pert Pro powder diffractometer with $X$ 'Celerator detector and variable divergence and fixed receiving slits, with Fe filtered Co-Ka radiation. The phases were identified using X'Pert Highscore plus software.

A Nicolet FT-IR 6700 Spectrometer was used to analyze samples in the band regions of $400-2000 \mathrm{~cm}^{-1}$. The spectra were obtained after dilution and compression of approximately $1 \mathrm{mg}$ of sample into $300 \mathrm{mg}$ of $\mathrm{KBr}$.

The equilibrium concentration of $\mathrm{Cr}(\mathrm{VI})$ in the solution was determined by reacting it with 1.5-diphenyl carbazide as chromogenic agent, and measuring the absorption with a PerkinElmer Lambda 25 UV-Visible spectrometer at the wavelength of $540 \mathrm{~nm}$.

\subsection{Experimental}

All $\mathrm{Cr}(\mathrm{VI})$ from the dust was leached out according to the ASTM D 3987-85 procedure [22], after which it was removed from the leachate and stabilized by adding exfoliated vermiculite to the leachate. Experiments were carried out with two different sets of $\mathrm{Cr}(\mathrm{VI})$-containing solutions. In the first set, ASTM D 3987-85 (Reapproved 2004) 
leachate from the FCD was used in order to investigate the effect of operating parameters on the removal of $\mathrm{Cr}(\mathrm{VI})$. In the second set, pure solutions of $\mathrm{Cr}(\mathrm{VI})$ at different dilutions were used in order to study the kinetics, isotherms and the effect of phase composition on $\mathrm{Cr}(\mathrm{VI})$ adsorption onto vermiculite.

All experiments were carried out at room temperature using a magnetic stirrer at $1000 \mathrm{rpm}, 100 \mathrm{~mL}$ of the test solution in a $200 \mathrm{~mL}$ beaker and the desired amount of adsorbent at different $\mathrm{pH}$ and contact times. At the end of the adsorption period, the supernatant solution was decanted and the adsorbent was filtered through a $0.45 \mu \mathrm{m}$ Whatman Grade NC 45 (Cellulose Nitrate Membrane) filter paper. The filtrate was then analysed for any remaining $\mathrm{Cr}(\mathrm{VI})$.

The operating parameters that were examined included the effect of $\mathrm{pH}$, adsorbent concentration and contact time on $\mathrm{Cr}(\mathrm{VI})$ removal efficiency. These parameters were varied in the following ranges:

- $\mathrm{pH}$ between 1 and 9;

- Adsorbent concentration between 2.5 and $12.5 \mathrm{mg} \mathrm{L}^{-1}$;

- Contact time between 10 and 150 minutes.

The kinetics of $\mathrm{Cr}(\mathrm{VI})$ adsorption onto vermiculite was studied at two initial $\mathrm{Cr}(\mathrm{VI})$ concentration levels ( 10 and $20 \mathrm{mg} \mathrm{L}^{-1}$ ), $10 \mathrm{~g} \mathrm{~L}^{-1}$ of adsorbent dosage, $\mathrm{pH} 1.5$ and contact time between 10 and 150 minutes.

The adsorption isotherm study was carried out with different initial $\mathrm{Cr}(\mathrm{VI})$ concentrations ranging from 10 to $100 \mathrm{mg} \mathrm{L}^{-1}$ at $\mathrm{pH} 1.5$, contact time of 120 minutes and $10 \mathrm{~g} \mathrm{~L}^{-1}$ of adsorbent dosage.

The amount of $\mathrm{Cr}(\mathrm{VI})$ adsorbed at any time per unit mass of the adsorbent and the removal efficiency of $\mathrm{Cr}(\mathrm{VI})$ were evaluated using equations (1) and (2), respectively.

$1 \quad q_{t}=\left(\frac{C_{i}-C_{t}}{W}\right) \times V$

2 Removal efficiency $(\%)=\left(\frac{C_{i}-C_{f}}{C_{i}}\right) \times 100$ 
where $\mathrm{q}_{\mathrm{t}}\left(\mathrm{mg} \mathrm{g}^{-1}\right)$ is the adsorption capacity at any time $\mathrm{t}, \mathrm{C}_{\mathrm{i}}\left(\mathrm{mg} \mathrm{L}^{-1}\right), \mathrm{C}_{\mathrm{t}}\left(\mathrm{mg} \mathrm{L}^{-1}\right)$ and $\mathrm{C}_{\mathrm{f}}$ $\left(\mathrm{mg} \mathrm{L}^{-1}\right)$ are respectively the initial $\mathrm{Cr}(\mathrm{VI})$ concentration, the $\mathrm{Cr}(\mathrm{VI})$ concentration at time $\mathrm{t}$, and the final $\mathrm{Cr}(\mathrm{VI})$ concentration, $\mathrm{V}(\mathrm{mL})$ is the volume of the solution and $\mathrm{W}(\mathrm{g})$ is the mass of adsorbent used. At equilibrium, $C_{f}$ equals $C_{e}$.

The influence of phase composition of the vermiculite on $\mathrm{Cr}(\mathrm{VI})$ uptake was investigated by means of Langmuir isotherms and XRD analyses, using vermiculite samples VER1, VER2 and VER3.

All experiments were carried out in triplicate. Average values are reported together with standard deviations.

\subsection{Desorption study}

To assess if the treated $\mathrm{FCD}$ and the $\mathrm{Cr}(\mathrm{VI})$-loaded vermiculite can safely be disposed of, $\mathrm{Cr}(\mathrm{VI})$ leachability from the two products was investigated by means of the Modified ASTM D 3987-85 (2004) [22] and TCLP Method 1311 [23] leaching tests over a period of 12 months. The ASTM test involved the continuous agitation of $5 \mathrm{~g}$ of sample in $100 \mathrm{~mL}$ of distilled water at $30 \mathrm{rpm}$ for 18 hours at room temperature, while the TCLP test consisted of $5 \mathrm{~g}$ of sample, added to $100 \mathrm{~mL}$ of TCLP solution No 1 (5.7 mL glacial acetic acid, $500 \mathrm{~mL}$ distilled water and $64.3 \mathrm{~mL}$ of $1 \mathrm{~N} \mathrm{NaOH}$ ), continuously agitated at $30 \mathrm{rpm}$ at room temperature for 20 hours. These Modified Leachate Extraction Procedures differ from the standard tests in that $5 \mathrm{~g}$ of solid sample were used instead of $70 \mathrm{~g}$ and $100 \mathrm{~g}$ for ASTM and TCLP, respectively. The solid-liquid ratio was kept unchanged at 1:20. $\mathrm{Cr}(\mathrm{VI})$ desorption from the $\mathrm{Cr}(\mathrm{VI})$-loaded vermiculite was also evaluated with the Acid Rain Test, during which the $\mathrm{Cr}(\mathrm{VI})$-loaded vermiculite was leached with a saturated solution of carbonic acid, called the acid rain solution [24]. This test involved adding $5 \mathrm{~g}$ of sample to $100 \mathrm{~mL}$ of acid rain solution, continuously agitating for 20 hours at room temperature. 


\section{Results and discussion}

\subsection{X-Ray Diffraction analysis of vermiculite sample VER1 before and after adsorption}

XRD analysis of the vermiculite VER1 sample before and after adsorption confirmed that the ratio in which the layered silicate phases vermiculite, biotite and hydrobiotite which constitute the VER1 sample, changes during the adsorption process (Fig. 1). It can be seen from Fig. 1 that sample VER1 contains more vermiculite, less hydrobiotite and possibly the same amount of biotite compared to the sample after adsorption. The major peak of the vermiculite phase at $2 \theta=7.2^{\circ}$, drastically decreased in intensity after adsorption. The decrease in the amount of the vermiculite phase observed in the $\mathrm{Cr}(\mathrm{VI})$ loaded vermiculite VER1 sample may be explained by the major role that the vermiculite phase plays in the adsorption process.

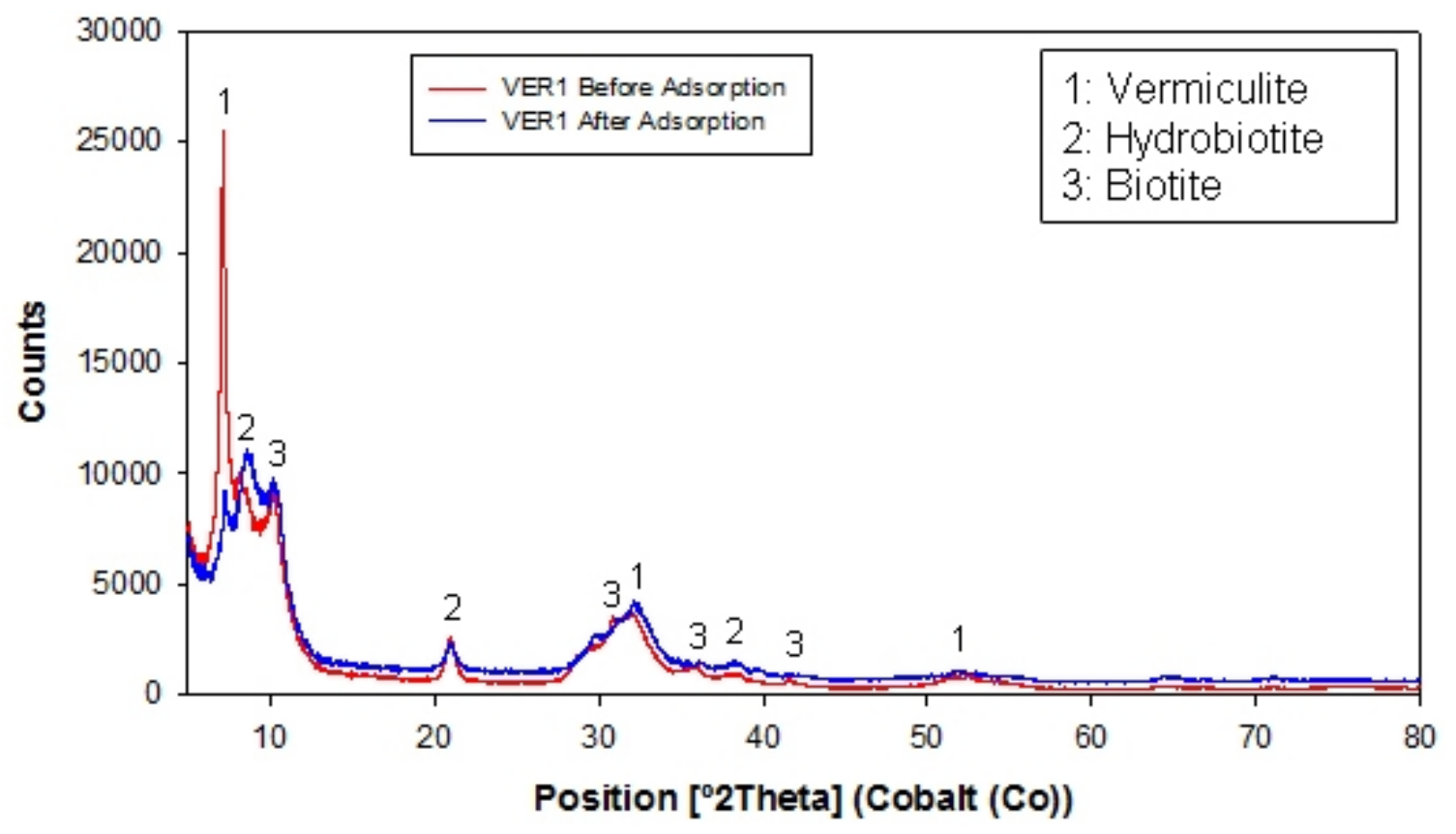

Fig. 1. XRD patterns of vermiculite sample VER1 before and after adsorption. 


\subsection{Fourier Transform Infrared (FT-IR) spectra of vermiculite sample VER1 before and after adsorption}

Fourier Transform Infrared (FT-IR) spectra of the adsorbent prior to and after adsorption are illustrated in Fig. 2. In the adsorbent before adsorption, the broad band observed at $3494.9 \mathrm{~cm}^{-1}$ may be assigned to $\mathrm{O}-\mathrm{H}$ stretching vibration of the hydroxyl groups including $\mathrm{Si}-\mathrm{OH}$ and $\mathrm{Al}-\mathrm{OH}$. The peak at $1631.5 \mathrm{~cm}^{-1}$ is attributed to bending vibration of water molecules. The broad band observed at $1002.3 \mathrm{~cm}^{-1}$ is assigned to stretching vibration of the Si-O-Si group. The peaks observed at $678.8 \mathrm{~cm}^{-1}$ and 443.6 $\mathrm{cm}^{-1}$ are due to the deforming and bending modes of the Si-O bonds of the tetrahedral sheet, respectively. After adsorption, the peaks observed at 3494.9 and $1631.5 \mathrm{~cm}^{-1}$ shifted slightly to 3385.5 and $1635.4 \mathrm{~cm}^{-1}$, respectively. These observed changes in vibration frequency in the functional groups were assumed to be due to $\mathrm{Cr}(\mathrm{VI})$ adsorption onto vermiculite.

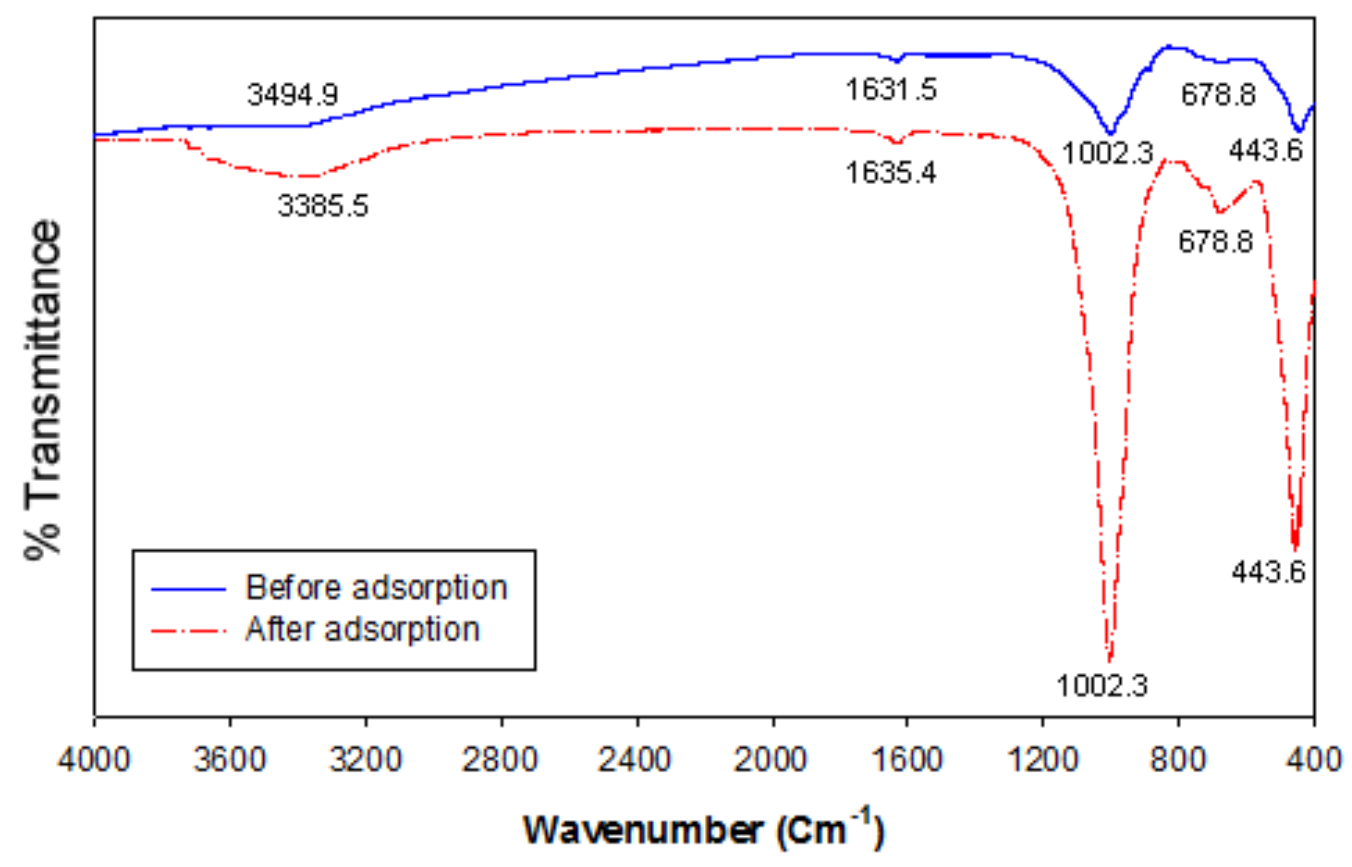

Fig. 2. FT-IR spectra of vermiculite sample VER1 before and after adsorption. 


\subsection{Effect of $\mathrm{pH}$}

The $\mathrm{pH}$ of an aqueous solution strongly affects the adsorption of heavy metals onto clay minerals [11]. $\mathrm{Cr}(\mathrm{VI})$ adsorption onto vermiculite was also found to be highly $\mathrm{pH}$ dependent, with a maximum $\mathrm{Cr}(\mathrm{VI})$ removal efficiency of $98.4 \%$ at $\mathrm{pH}$ between 1.0 and 2.0 (Fig. 3). $\mathrm{Cr}(\mathrm{VI})$ adsorption drastically decreases with increasing $\mathrm{pH}$. This is explained by the fact that in aqueous solution, the distribution of $\mathrm{Cr}(\mathrm{VI})$ species mainly depends on solution $\mathrm{pH}$ and $\mathrm{Cr}(\mathrm{VI})$ concentration according to the following equilibria [25]:

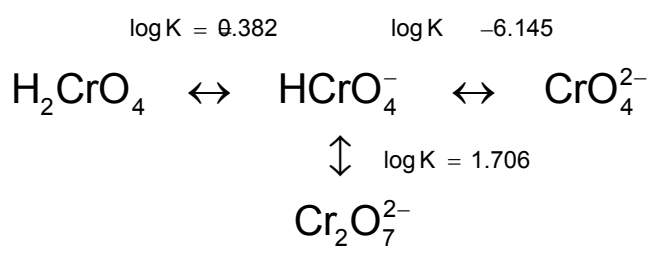

At low $\mathrm{pH}$ (acidic conditions) the predominant form of $\mathrm{Cr}(\mathrm{VI})$ is hydrochromate $\left(\mathrm{HCrO}_{4}^{-}\right)$, which is the product of the hydrolysis reaction of the dichromate $\left(\mathrm{Cr}_{2} \mathrm{O}_{7}^{2-}\right)$ and chromate $\left(\mathrm{CrO}_{4}^{2-}\right)$, while at high $\mathrm{pH}$ (basic conditions), the predominant forms of $\mathrm{Cr}(\mathrm{VI})$ are $\mathrm{Cr}_{2} \mathrm{O}_{7}^{2-}$ and $\mathrm{CrO}_{4}^{2-}$. Better adsorption observed at low $\mathrm{pH}$ is attributed to the large number of $\mathrm{H}^{+}$ions in solution, which protonate the surface of the vermiculite as follows:

$$
\begin{aligned}
& \equiv \mathrm{Si}-\mathrm{OH}+\mathrm{H}^{+} \leftrightarrow \equiv \mathrm{Si}-\mathrm{OH}_{2}^{+} \\
& \equiv \mathrm{Al}-\mathrm{OH}+\mathrm{H}^{+} \leftrightarrow \equiv \mathrm{Al}-\mathrm{OH}_{2}^{+}
\end{aligned}
$$

A high electrostatic attraction between hydrochromate $\left(\mathrm{HCrO}_{4}^{-}\right)$and the protonated surface of vermiculite therefore results. A further decrease in $\mathrm{pH}$ was found to have an insignificant effect on removal efficiency. This can be explained by the fact that the adsorption reaction has reached equilibrium at $\mathrm{pH}$ 1.5. The equilibrium $\mathrm{pH}$ can therefore be taken as the optimal $\mathrm{pH}$ for $\mathrm{Cr}(\mathrm{VI})$ adsorption. 


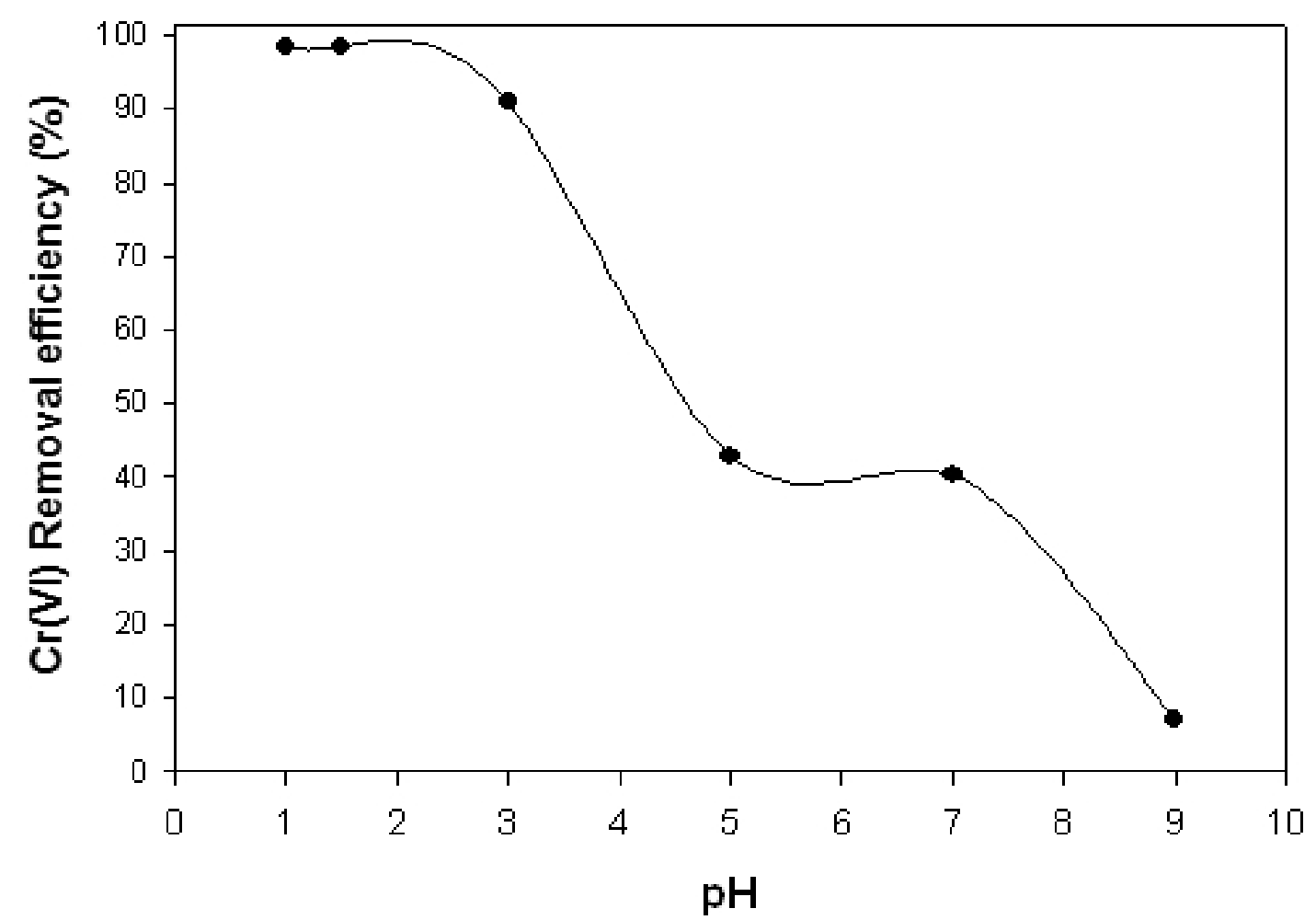

Fig. 3. Effect of $\mathrm{pH}$ on $\mathrm{Cr}(\mathrm{VI})$ removal efficiency (adsorbent dosage $10 \mathrm{~g} \mathrm{~L}-1$ and contact time of $120 \mathrm{~min}$ ).

\subsection{Effect of adsorbent concentration with contact time}

Adsorbent dosage and contact time are important parameters in the adsorption process. The effect of adsorbent concentration on removal efficiency was investigated at different contact times and initial pHs, ranging from 10 to 150 minutes, and 1 to 9 , respectively. The highest $\mathrm{Cr}(\mathrm{VI})$ removal efficiency was obtained at $\mathrm{pH} 1.5$ and 120 minutes of contact time. It is apparent from Fig. 4 that the process is enhanced by increasing the contact time and the adsorbent dosage until equilibrium is reached at 120 minutes and $10 \mathrm{~g} \mathrm{~L}^{-1}$. A further increase in contact time and adsorbent dosage had an insignificant effect on $\mathrm{Cr}(\mathrm{VI})$ uptake. According to Bansal et al. [12], this can be explained by the fact that the higher the dose of adsorbent in the solution, the greater the surface area, the greater the availability of active sites and the easier the adsorption of $\mathrm{Cr}(\mathrm{VI})$. However, the magnitude of uptake capacity could have decreased with an increment in adsorbent dosage due to overlapping of adsorption sites as a result of overcrowding of adsorbent particles. 


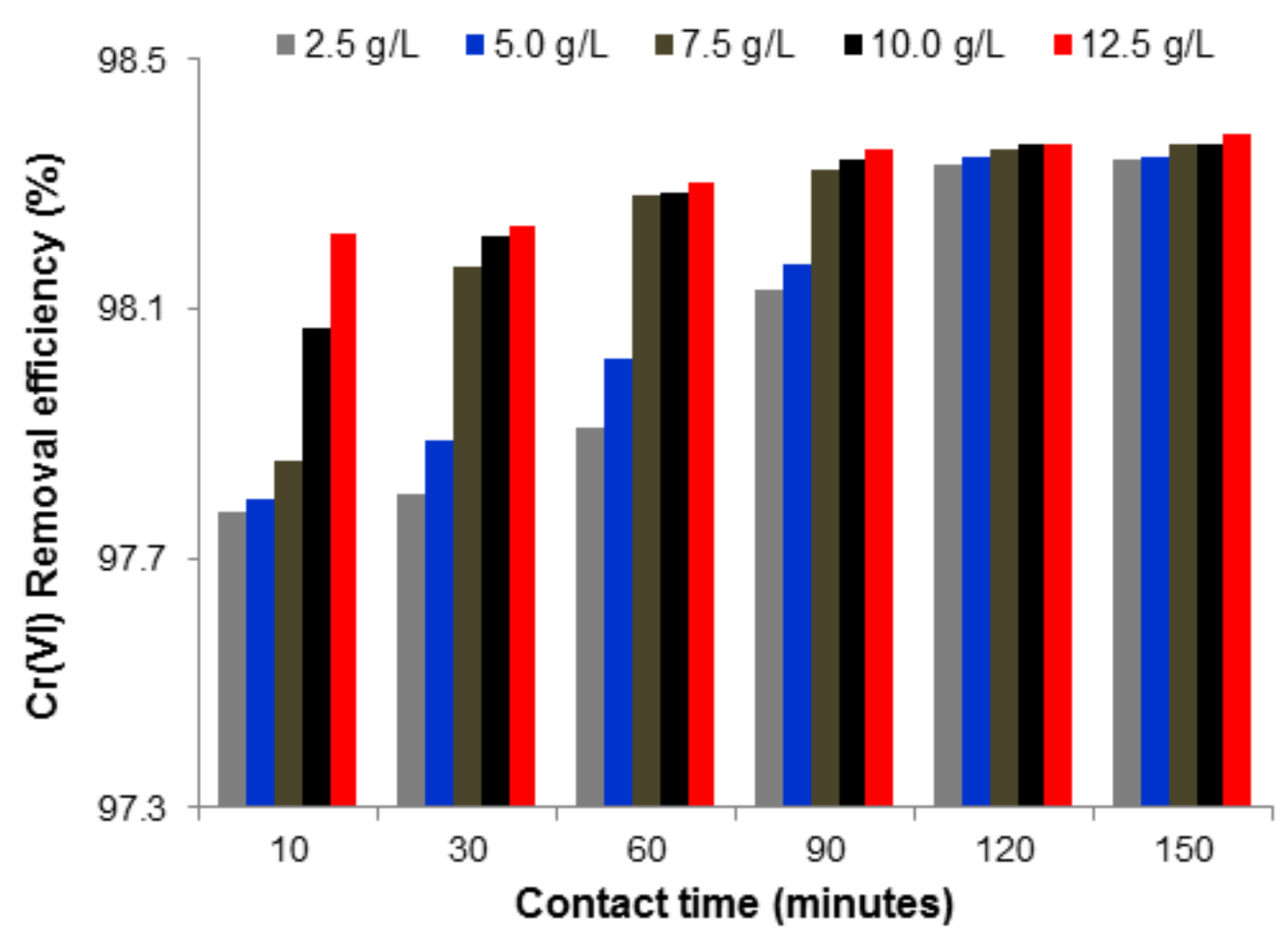

Fig. 4. Effect of adsorbent concentration with contact time on $\mathrm{Cr}(\mathrm{VI})$ removal efficiency at $\mathrm{pH} 1.5$.

\subsection{Adsorption Kinetics}

In order to investigate the kinetics of the present adsorption process, equilibrium data were used to fit to Lagergren models such as pseudo-first order (equation 3 ) and pseudo-second order (equation 5) equations [26-28].

For an adsorption process that obeys the first order rate law, the reaction rate constant is given by the linear form of the following expression:

$3 \quad \frac{d q}{d t}=k_{1}\left(q_{e}-q\right)$

While the linear form of equation (3) can be expressed as:

$4 \quad \ln \left(q_{e}-q\right)=\ln q_{e}-k_{1} t$

where $\mathrm{q}_{\mathrm{e}}$ and $\mathrm{q}$ are the amounts of chromium adsorbed $\left(\mathrm{mg} \mathrm{g}^{-1}\right)$ at equilibrium and at any time $t$ ( $\min$ ), respectively, and $k_{1}$ is the Lagergren rate constant of the pseudo-first order 
adsorption $\left(\mathrm{min}^{-1}\right)$. Values of $\mathrm{k}_{1}$ and $\mathrm{q}_{\mathrm{e}}$ were calculated from the slope and intercept of the plots of $\ln \left(q_{e}-q\right)$ versus $t$ respectively.

The second order kinetic model can be represented as follows:

$5 \quad \frac{d q}{d t}=k_{2}\left(q_{e}-q\right)^{2}$

while the linear form of equation (5) can be expressed as:

$6 \quad \frac{t}{q}=\frac{1}{k_{2} q_{e}^{2}}+\frac{t}{q_{e}}$

where $\mathrm{k}_{2}$ is the equilibrium rate constant of second order adsorption $\left(\mathrm{g} \mathrm{mg}^{-1} \mathrm{~min}^{-1}\right)$. Values of $\mathrm{k}_{2}$ and $\mathrm{q}_{\mathrm{e}}$ were calculated from the plots of $\mathrm{t} / \mathrm{q}$ versus $t$.

Kinetic parameters including rate constants for the adsorption of $\mathrm{Cr}(\mathrm{VI})$ onto vermiculite were evaluated by means of the linear forms of the Lagergren equations (4) and (6). The values for these parameters, along with their correlation coefficients, are presented in Table 2. Comparison of the regression coefficients confirms that the experimental data obey the pseudo-second order Lagergren equation.

Table 2. The kinetic parameters evaluated for the adsorption of $\mathrm{Cr}(\mathrm{VI})$ onto vermiculite $(\mathrm{pH}$ 1.5 , adsorbent dosage $10 \mathrm{~g} . \mathrm{L}^{-1}$ and contact time 120 minutes).

\begin{tabular}{|c|c|c|c|c|c|c|c|}
\hline \multirow{2}{*}{$C_{0}\left(m g \cdot L^{-1}\right)$} & \multirow{2}{*}{$q_{e} \exp \cdot\left(m g \cdot g^{-1}\right)$} & \multicolumn{3}{|c|}{ Pseudo-first order } & \multicolumn{3}{|c|}{ Pseudo-second order } \\
\hline & & $\overline{\mathrm{K}_{1}}$ & $q_{e}$ & $\mathbf{R}^{2}$ & $\overline{\mathbf{K}_{2}}$ & $q_{e}$ & $\mathbf{R}^{2}$ \\
\hline 10 & 8.63 & 0.051 & 8.478 & 0.868 & 0.010 & 9.433 & 0.998 \\
\hline 20 & 12.07 & 0.014 & 3.481 & 0.952 & 0.006 & 12.928 & 0.987 \\
\hline
\end{tabular}

\subsection{Adsorption Isotherms}

Several mathematical models have been developed to quantitatively express the relationship between the extent of adsorption and the residual solute concentration. In this 
study, Freundlich and Langmuir adsorption isotherm models were selected to fit the experimental data $[12,13,27,29,30,31]$.

The adsorption isotherm studies were carried out with $\mathrm{Cr}(\mathrm{VI})$ at different initial concentrations ranging from 10 to $100 \mathrm{mg} \mathrm{L}^{-1}$, and the adsorbent concentration of $10 \mathrm{~g} \mathrm{~L}^{-1}$. The equilibrium amount of $\mathrm{Cr}(\mathrm{VI})\left(\mathrm{q}_{\mathrm{e}}\right)$ adsorbed per unit mass of the adsorbent $\left(\mathrm{mg} \mathrm{g}^{-1}\right)$ is given by the following equation:

$7 \quad q_{e}=\frac{W_{i}-W_{e}}{m}$

where $\mathrm{W}_{\mathrm{i}}$ and $\mathrm{W}_{\mathrm{e}}$ are respectively the initial and equilibrium amounts $(\mathrm{mg})$ of $\mathrm{Cr}(\mathrm{VI})$ in solution, and $\mathrm{m}$ is the mass of the adsorbent $(\mathrm{g})$.

\subsubsection{Freundlich isotherm}

The Freundlich isotherm expresses a multilayer adsorption, with a heterogeneous energetic distribution of active sites, accompanied by interaction between adsorbed molecules [12]. The plot of this model indicates that the highest fraction of the sorbate species is observed at the lowest sorbate concentrations [30].

The non linear and linear forms of the Freundlich isotherm are given by equations (8) and (9) respectively.

$$
\begin{aligned}
& 8 \quad \mathrm{q}_{\mathrm{e}}=\mathrm{K}_{\mathrm{F}} \mathrm{C}_{\mathrm{e}}^{1 / \mathrm{n}} \\
& 9 \quad \ln \mathrm{q}_{\mathrm{e}}=\ln \mathrm{K}_{\mathrm{F}}+\frac{1}{\mathrm{n}} \ln \mathrm{C}_{\mathrm{e}}
\end{aligned}
$$

where $\mathrm{q}_{\mathrm{e}}$ is the equilibrium adsorption capacity $\left(\mathrm{mg} \mathrm{g}^{-1}\right), \mathrm{K}_{\mathrm{F}}$ and $1 / \mathrm{n}$ are constants related to adsorption capacity and adsorption intensity respectively, $\mathrm{C}_{\mathrm{e}}$ is the equilibrium aqueous concentration $\left(\mathrm{mg} \mathrm{L}^{-1}\right) \cdot \mathrm{K}_{\mathrm{F}}$ and $\mathrm{n}$ are determined from the intercept and slope of the linear plots of $\ln \mathrm{q}_{\mathrm{e}}$ versus $\ln \mathrm{C}_{\mathrm{e}}$, respectively. An adsorbent is regarded as preferable if the value of $1 / \mathrm{n}$ lies between 0 and 1 [30]. 


\subsubsection{Langmuir isotherm}

The Langmuir isotherm is valid for instances where adsorption is a monolayer coverage process. It is therefore expected that adsorption values reach a maximum at high adsorbate concentrations [30]. Adsorption takes place at specific homogeneous sites within the adsorbent and once a metal ion occupies a site, no further adsorption occurs at that site [32].

The non linear and linear forms of the Langmuir isotherm are given by equations (10) and (11) respectively:

$10 \quad q_{e}=\frac{K_{L} q_{m} C_{e}}{1+K_{L} C_{e}}$

$11 \quad \frac{\mathrm{C}_{e}}{\mathrm{q}_{\mathrm{e}}}=\frac{1}{\mathrm{q}_{\mathrm{m}} \mathrm{K}_{\mathrm{L}}}+\frac{\mathrm{C}_{\mathrm{e}}}{\mathrm{q}_{\mathrm{m}}}$

where $\mathrm{q}_{\mathrm{e}}$ is the amount of adsorbate adsorbed by a unit mass of adsorbent at equilibrium $\left(\mathrm{mg} \mathrm{g}^{-1}\right), \mathrm{C}_{\mathrm{e}}$ the concentration of adsorbate remaining in the solution at equilibrium ( $\mathrm{mg} \mathrm{L}^{-}$ $\left.{ }^{1}\right), K_{L}$ the constant related to the adsorption net enthalpy, $q_{m}$ the maximum adsorption capacity or amount of adsorbate adsorbed by unit mass of adsorbent that is required to cover the sorbent surface completely as a monolayer $\left(\mathrm{mg} \mathrm{g}^{-1}\right)$. $\mathrm{q}_{\mathrm{m}}$ and $\mathrm{K}_{\mathrm{L}}$ are evaluated from the slope and intercept of the linear plots of $C_{e} / q_{e}$ versus $C_{e}$, respectively.

\subsubsection{Results on the isotherm study}

Experimental data of the mass of solute adsorbed per unit mass of adsorbent, were fitted to equations (8), (9), (10) and (11), which represent the non-linear and linear forms of the Freundlich and Langmuir adsorption isotherms, respectively. Values for the Freundlich and Langmuir constants, as well as their correlation coefficients are presented in Table 3. The non-linear plot of the Freundlich and Langmuir isotherms along with the experimental data isotherm are shown in Fig. 5. The maximum adsorption capacity $q_{m}$ and Langmuir 
equilibrium constant $K_{L}$ of the vermiculite (sample VER1) were found to be $23.25 \mathrm{mg} \mathrm{g}^{-1}$ and $0.15 \mathrm{~L} \mathrm{~g}^{-1}$, respectively.

Constants related to the adsorption capacity $\mathrm{K}_{\mathrm{F}}$ and adsorption intensity $\mathrm{n}$ were found to be 7.87 and 4.15 , respectively. Since the value of $1 / \mathrm{n}$ is between 0 and 1 , the adsorption of $\mathrm{Cr}(\mathrm{VI})$ onto vermiculite under studied conditions was favourable [30]. Although the experimental data fitted both adsorption models, the high value of the correlation coefficient associated with the Langmuir model $\left(R^{2}=0.996\right.$ compared to 0.988 for the Freundlich isotherm) suggests monolayer coverage of the $\mathrm{Cr}(\mathrm{VI})$ on the surface of the vermiculite $[30,32]$.

Table 3. The isotherm parameters and regression coefficients obtained for $\mathrm{Cr}(\mathrm{VI})$ adsorption data ( $\mathrm{pH}$ 1.5, adsorbent dosage $10 \mathrm{~g} \cdot \mathrm{L}^{-1}$ and contact time 120 minutes).

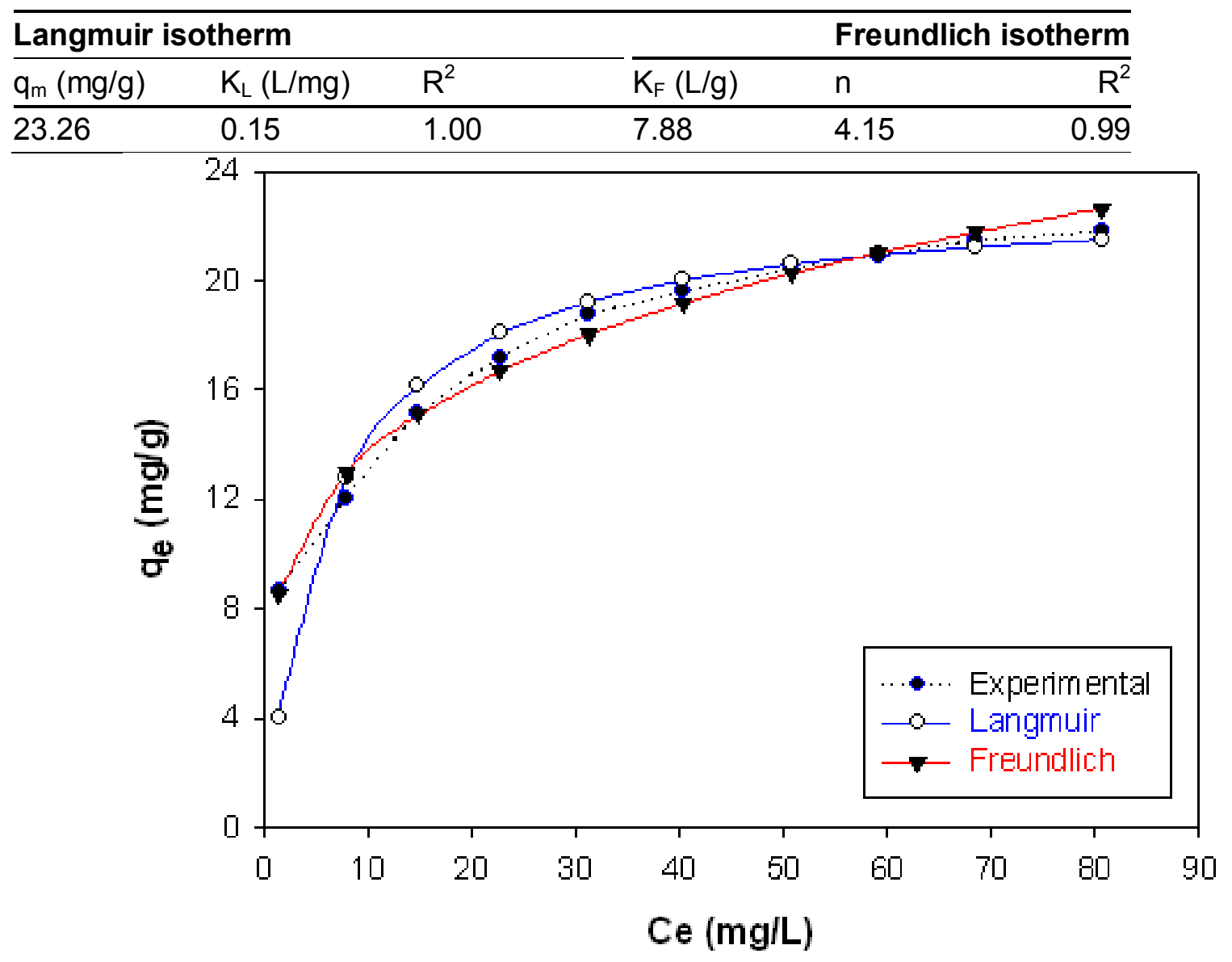

Fig. 5. Non-linear isotherm plots for $\mathrm{Cr}(\mathrm{VI})$ adsorption onto vermiculite $(\mathrm{pH} 1.5$; adsorbent dosage $10 \mathrm{~g} \mathrm{~L}-1$ and contact time $120 \mathrm{~min}$ ). 


\subsection{Effect of phase composition on $\mathrm{Cr}(\mathrm{VI})$ uptake}

XRD patterns of vermiculite samples VER1, VER2 and VER3 indicate that these industrial vermiculite samples contain varying amounts of the phases vermiculite, biotite and hydrobiotite (Fig. 6). It can be seen from these patterns that vermiculite samples VER1 and VER2 contain more vermiculite, and less hydrobiotite compared to vermiculite sample VER3. Sample VER1 contains more biotite than samples VER2 and VER3. The significance of hydrobiotite in sample VER3 is also confirmed by the high Loss On Ignition. The hydrobiotite as well as the vermiculite in sample VER3 is presumably more crystalline than those of VER1 and VER2 (reflected by sharper peaks), while the biotite in sample VER2 seems to be more crystalline than the biotite in sample VER1. It can be concluded that vermiculite sample VER2 is purer than samples VER1 and VER3.

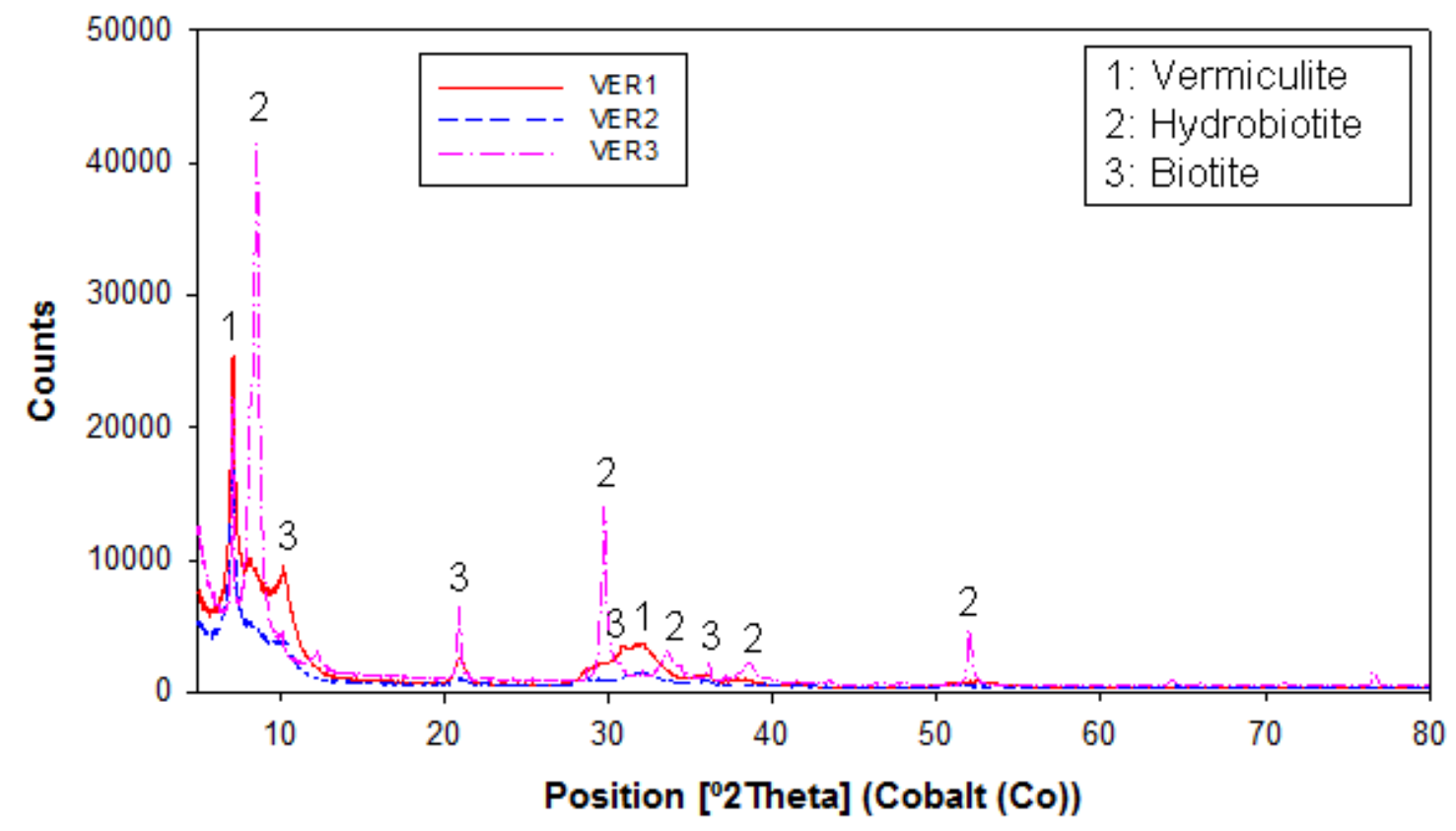

Fig. 6. XRD patterns of vermiculite samples VER1, VER2 and VER3.

Langmuir isotherm parameters and regression coefficients corresponding to $\mathrm{Cr}(\mathrm{VI})$ adsorption onto vermiculite samples VER1, VER2 and VER3 are given in Table 4. Since the maximum uptake of $\mathrm{Cr}(\mathrm{VI})$ onto the three exfoliated vermiculite samples slightly decreases with a decrease in the concentration of the vermiculite phase, it can be 
concluded that the vermiculite phase is the major phase responsible for adsorption of $\mathrm{Cr}(\mathrm{VI})$ onto industrially supplied vermiculite.

Table 4. The isotherm parameters and regression coefficients obtained for $\mathrm{Cr}(\mathrm{VI})$ adsorption data (10 g. $\mathrm{L}^{-1}$ of vermiculite at $20^{\circ} \mathrm{C}, \mathrm{pH} 1.5$ and 120 minutes).

\begin{tabular}{lllr}
\hline Vermiculite Samples & $\left.\mathbf{q}_{\mathbf{m}} \mathbf{( m g} \mathbf{g}^{-1}\right)$ & $\mathbf{K}_{\mathbf{L}}\left(\mathbf{L} \cdot \mathbf{m g}^{-1}\right)$ & $\mathbf{R}^{\mathbf{2}}$ \\
\hline VER1 & 23.26 & 0.15 & 1.00 \\
VER2 & 29.91 & 0.16 & 0.99 \\
VER3 & 22.46 & 0.16 & 0.99 \\
\hline
\end{tabular}

\subsubsection{Comparison of $\mathrm{Cr}(\mathrm{VI})$ adsorption capacities of vermiculite against other sorbents}

Table 5. Summary of $\mathrm{Cr}(\mathrm{VI})$ adsorption capacities of vermiculite compared to other sorbents

\begin{tabular}{|l|c|c|}
\hline \multicolumn{1}{|c|}{ Sorbent } & $\begin{array}{c}\text { Adsorption Capacity } \\
\text { (mg/g) }\end{array}$ & Reference \\
\hline \multicolumn{1}{|c|}{ This study } & $22.46-29.91$ & \\
\hline Inorganic Sorbents & 87.7 & {$[29]$} \\
Vermiculite ${ }^{2+}$ modified vermiculite & 87.72 & {$[33]$} \\
Raw Indian vermiculite & $5.1-7.3$ & {$[34]$} \\
Kaolinite & $10.6-13.9$ & {$[35]$} \\
Montmorillonite & 41.34 & {$[36]$} \\
Zeolite & $0.4-0.7$ & {$[37]$} \\
Calcined bauxite & 2.0 & {$[38]$} \\
Riverbed sand & 0.2 & {$[39]$} \\
Activated carbon & $10.0-74.5$ & {$[40,41]$} \\
\hline Organic sorbents & & {$[42]$} \\
\hline Chitosan & 27.3 & {$[26]$} \\
Coconut coir pith & 76.3 & {$[43,44]$} \\
Fly ash & $4.3-15.58$ & \\
\hline
\end{tabular}




\begin{tabular}{|c|c|c|}
\hline $\begin{array}{l}\text { Peat moss } \\
\text { Sawdust } \\
\text { Tamarind seeds }\end{array}$ & $\begin{array}{c}43.0 \\
2.7-39.7 \\
29.7\end{array}$ & $\begin{array}{c}{[45]} \\
{[46,47]} \\
{[48]}\end{array}$ \\
\hline \multicolumn{3}{|l|}{ Micro-organisms } \\
\hline $\begin{array}{r}\text { Escherichia coli supported on } \\
\text { kaolin } \\
\text { Arthrobacter viscosus } \\
\text { supported on granular activated } \\
\text { carbon }\end{array}$ & $11.35-14.55$ & [49] \\
\hline
\end{tabular}

The maximum $\mathrm{Cr}(\mathrm{VI})$ adsorption capacity of the vermiculite tested in this study (22.46 - $29.91 \mathrm{mg} \mathrm{g}^{-1}$ at pH 1.5) is significantly less than the values reported by Sari and Tuzen for Turkish vermiculite (87.7 $\mathrm{mg} \mathrm{g}^{-1}$ at $\mathrm{pH} 1.5$, [29]), and by Liu et al., for $\mathrm{Fe}^{2+}$ modified vermiculite (87.72 $\mathrm{mg} \mathrm{g}^{-1}$ at $\mathrm{pH} 1$, [33]), but higher than the capacities reported by Jayabalakrishnan and Mahimaraja for different grades of raw Indian vermiculites (5.1 - 7.3 $\left.\mathrm{mg} \mathrm{g}^{-1},[34]\right)$ (Table 5). It is therefore clear that the nature of the vermiculite plays a significant role in its ability to adsorb $\mathrm{Cr}(\mathrm{VI})$ in aqueous solution.

When comparing the capacity of vermiculite to adsorb $\mathrm{Cr}(\mathrm{VI})$ to other adsorbents it is clear that exfoliated vermiculite remains a viable treatment option due to its high adsorption capacity, availability and low cost (Table 5). The absorption capacity of vermiculite is higher than that of kaolinite [35], zeolite [37], calcined bauxite [38], river bed sand [39], fly ash [43,44] and certain micro-organisms [49,50], and potentially also higher than that of montmorillonite [36], activated carbon [40,41], chitosan [42], coconut coir pitch [26], peat moss [45] and tamarind seeds [48].

\subsection{Long term stability of treated ferrochrome dust and $\mathrm{Cr}(\mathrm{VI})$-loaded vermiculite}

The treated FCD and $\mathrm{Cr}(\mathrm{VI})$-loaded vermiculite were analyzed monthly over a 12 month period for liberation of any $\mathrm{Cr}(\mathrm{VI})$, using the ASTM and TCLP methods. No additional $\mathrm{Cr}(\mathrm{VI})$ leached from the treated $\mathrm{FCD}$ over this test period of twelve months (Table 6). Evaluation of the $\mathrm{Cr}(\mathrm{VI})$-loaded vermiculite showed that the concentration of $\mathrm{Cr}(\mathrm{VI})$ in the leachate was below the regulation limit, and beyond 3 months, no additional 
$\mathrm{Cr}(\mathrm{VI})$ leached. The low degree of $\mathrm{Cr}(\mathrm{VI})$ desorption from the $\mathrm{Cr}(\mathrm{VI})$-loaded vermiculite suggests the chemisorption of $\mathrm{Cr}(\mathrm{VI})$ onto the vermiculite surface. However, desorption of $\mathrm{Cr}(\mathrm{VI})$ using the Acid Rain Test, resulted in $\mathrm{Cr}(\mathrm{VI})$ levels above the South African regulation limit.

According to the results obtained, the concentration of $\mathrm{Cr}(\mathrm{VI})$ leached was almost the same between ASTM and TCLP methods. The most significant difference between the ASTM and TCLP tests is the $\mathrm{pH}$ associated with these tests: When the ferrochrome dust was leached in the ASTM test, a pH of 9.07 resulted, while when the TCLP test was used the $\mathrm{pH}$ was 4.43. The $\mathrm{pH}$ generated when the $\mathrm{Cr}(\mathrm{VI})$-loaded vermiculite sample VER1 was leached with the Acid Rain Test was 4.87, resulting in an amount of $\mathrm{Cr}(\mathrm{VI})$ that leached which was greater than the amount allowed by regulatory agencies. This is presumable due to the presence of the $\mathrm{HCO}_{3}{ }^{-}$ion which competed with the hydrochromate anion for the adsorption site.

Table 6. Results of $\mathrm{Cr}(\mathrm{VI})$ leaching from stabilized matrix.

\begin{tabular}{|c|c|c|c|c|}
\hline \multirow{3}{*}{ Time (Days) } & \multicolumn{4}{|c|}{$\mathrm{Cr}(\mathrm{VI})$ Leached $\left(\mathrm{mg} \cdot \mathrm{L}^{-1}\right)$} \\
\hline & \multicolumn{2}{|c|}{ Treated Ferrochrome Dust } & \multicolumn{2}{|c|}{ Cr(VI)-Loaded Vermiculite } \\
\hline & ASTM & TCLP & ASTM & TCLP \\
\hline 30 & (a) & (a) & 0.012 & 0.013 \\
\hline 60 & - & - & 0.012 & 0.014 \\
\hline 90 & - & - & & (a) \\
\hline 120 & - & - & (a) & (a) \\
\hline 150 & - & - & (a) & (a) \\
\hline 180 & - & - & (a) & (a) \\
\hline 210 & (a) & (a) & (a) & (a) \\
\hline 240 & - & - & (a) & (a) \\
\hline 270 & - & - & (a) & (a) \\
\hline 300 & - & - & (a) & (a) \\
\hline 330 & - & - & (a) & (a) \\
\hline 360 & (a) & (a) & (a) & (a) \\
\hline
\end{tabular}




\section{Conclusions}

This batch adsorption study proved that South African vermiculite can be used to remove $\mathrm{Cr}(\mathrm{VI})$ from fine ferrochrome dust after it was leached in aqueous solution. Measurement over a 12 month period showed that no additional $\mathrm{Cr}(\mathrm{VI})$ leached from the treated ferrochrome dust. The FCD can therefore safely be disposed of.

The adsorption process was found to be highly $\mathrm{pH}$ dependent. The optimum $\mathrm{pH}$ for $\mathrm{Cr}(\mathrm{VI})$ adsorption onto vermiculite was found to be 1.5. The adsorption capacity is reduced when the $\mathrm{pH}$ if further increased. Adsorption increased with an increase in contact time and reached equilibrium after 2 hours. It was also observed that the adsorption of $\mathrm{Cr}(\mathrm{VI})$ onto vermiculite is rapid in the initial stages, followed by a progressive uptake. After equilibrium was reached, no significant change in uptake was observed. Increase in adsorbent dosage led to an increase in $\mathrm{Cr}(\mathrm{VI})$ adsorption. The optimum $\mathrm{Cr}(\mathrm{VI})$ uptake was obtained at an adsorbent dosage of $10 \mathrm{~g} \mathrm{~L}^{-1}$.

$\mathrm{XRD}$ analysis of the adsorbent showed that the major peak of the vermiculite phase at $2 \theta=7.2^{\circ}$ drastically decreased in intensity after adsorption. It was also observed that the extent of $\mathrm{Cr}(\mathrm{VI})$ adsorption onto vermiculite slightly increases with an increase in concentration of the vermiculite phase, which confirms the major role of the vermiculite phase in the adsorption process.

The $\mathrm{Cr}(\mathrm{VI})$-loaded vermiculite also remained unchanged over 12 months, when it was evaluated with the ASTM and TCLP leaching methods. However, $\mathrm{Cr}(\mathrm{VI})$ was released from the vermiculite up to concentrations above the South African regulation limit of 0.02 $\mathrm{mg} \mathrm{L}^{-1}$, when the vermiculite was evaluated with the Acid Rain Test.

\section{Acknowledgments}

The authors would like to thank THRIP (Technology and Human Recourses for Industry Program) for financial support. Special thanks are also due to Xstrata Lydenburg for supplying the ferrochrome dust, Vesuvius SA and Mandoval Vermiculite (Pty) Ltd South Africa for supplying the industrial grade vermiculite, and to Prof. Johan de Villiers, 
Department of Materials Science and Metallurgical Engineering, University of Pretoria, for valuable discussions.

\section{References}

[1] International Chromium Development Association (ICDA), Statistical bulletin. Paris, France, 2009.

[2] J.F. Papp, Chromium. U.S. Geological Survey Minerals Year Book, 2007. http://minerals.usgs.gov/minerals/pubs/commodity/chromium/myb1-2007-chrom.xls

[3] A. M. Garbers-Craig, G. Ma, $\mathrm{Cr}(\mathrm{VI})$-containing electric furnace dust and filter cake: Characteristics, formation, leachability and stabilization, $\mathrm{PhD}$ Thesis, University of Pretoria, Pretoria, Republic of South Africa, 2006.

[4] K. Pillay, H. von Blottnitz, J. Petersen, Ageing of chromium(III)-bearing slag and its relation to the atmospheric oxidation of solid chromium(III)-oxide in the presence of calcium oxide, Chemosphere. 52 (2003) 1771-1779.

[5] J. Barnhart, Occurrence, uses and properties of chromium, Regul Toxicol Pharmacol. 26 (1997) S3-S7.

[6] C. D. Palmer, P. R. Wittbrodt, Processes affecting the remediation of chromiumcontaminated sites, Environ Health Perspect. 92 (1991) 25-40.

[7] A. E. Pagana, S.D. Sklari, E.S. Kikkinides, V.T. Zaspalis, Microporous ceramic membrane technology for the removal of arsenic and chromium ions from contaminated water, Microporous Mesoporous Mater. 110 (2008) 150-156.

[8] M. G. da Fonseca, M.M. de Oliveira, L.N.H. Arakaki, J.G.P. Espinola, C. Airoldi, Natural vermiculite as an exchanger support for heavy cations in aqueous solutions, $\mathrm{J}$ Colloid Interf Sci. 285 (2005) 50-55.

[9] S. Itoh, H. Shimada, Clastogenicity and mutagenicity of hexavalent chromium in lacZ transgenic mice, Toxicol. Lett. 91 (1997) 229-33.

[10] A.K. Patlolla, C. Barnes, C. Yedjou, V.R. Velma, P.B. Tchounwou, Oxidative stress, DNA damage, and antioxidant enzyme activity induced by hexavalent chromium in Sprague-Dawley rats, Environ Toxicol. 24 (2009) 66-73. 
[11] Independent Environmental Technical Evaluation Group (IETEG), Chromium(VI) Handbook, CRC Press, Florida, USA, 2005.

[12] M. Bansal, D. Singha, V.K. Garg, A comparative study for the removal of hexavalent chromium from aqueous solution by agriculture wastes carbons, J Hazard. Mater. 171 (2009) 83-92.

[13] M. G. da Fonseca, M.M. de Oliveira, L.N.H. Arakaki, Removal of cadmium, zinc, manganese and chromium cations from aqueous solution by a clay mineral, $\mathrm{J}$ Hazard. Mater. B137 (2006) 288-292.

[14] G. Laforest, J. Duchesne, Evaluation of the degree of Cr ions immobilization by different binders, Cem. Concr. Res. 35 (2004) 1173-1177.

[15] G. Laforest, J. Duchesne, Immobilization of chromium (VI) evaluated by binding isotherms for ground granulated blast furnace slag and Ordinary Portland Cement, Cem. Concr. Res. 35 (2005) 2322-2332.

[16] S.E. Bailey, T.J. Olin, R.M. Bricka, D. Adrian, A review of potentially low-cost sorbents for heavy metals, Water Res. 33 (1999) 2469-2479.

[17] U.S. Environmental Protection Agency (U.S.EPA), In situ treatment of soil and groundwater contaminated with chromium, EPA/625/R-00/005, October 2000.

[18] D. Mulange Wa Mulange, Stabilizatio of $\mathrm{Cr}(\mathrm{VI})$ from fine ferrochrome dust using exfoliated vermiculite, MSc thesis, University of Pretoria, South Africa, 2011.

[19] American Society for Testing and Materials (ASTM), Standard Test Method for Screening Apparent Specific Gravity and Bulk Density of Waste, Method D 5057-90 (Reapproved 2006), ASTM, PA, USA.

[20] American Society for Testing and Materials (ASTM), Standard Test Method for Screening of pH in Waste, Method D 4980-89 (Reapproved 2003), ASTM, PA, USA.

[21] International Atomic Energy Agency (IAEA), Field estimation of soil water content: A practical guide to methods, instrumentation and sensor technology, IAEA, Vienna, Austria, 2008.

[22] American Society for Testing and Materials (ASTM), Standard Test Method for Shake Extraction of Solid Waste with Water, Method D 3987-85 (Reapproved 2004), ASTM, PA, USA. 
[23] US Environmental Protection Agency (U.S.PEA), Toxicity Characteristic Leaching Procedure (Method 1311 Revision 0, Jul. 1992). EPA, July 1992.

[24] Department of Water Affairs and Forestry (DWAF), Minimum Requirements for the Handling, Classification and Disposal of Hazardous Waste, second ed., Johannesburg, Republic of South Africa, 1998.

[25] X.S. Wang, Y.P. Tang, S.R. Tao, Kinetics, equilibrium and thermodynamic study on removal of $\mathrm{Cr}(\mathrm{VI})$ from aqueous solutions using low-cost adsorbent Alligator weed, Chem. Eng. J. 148 (2009) 217-225.

[26] C. Namasivayam, M.V. Sureshkumar, Removal of chromium(VI) from water and wastewater using surfactant modified coconut coir pith as a biosorbent, Bioresource Technology 99 (2008) 2218-2225.

[27] M. Uysal, A. Irfan, Removal of $\mathrm{Cr}(\mathrm{VI})$ from industrial wastewaters by adsorption. Part I: Determination of optimum conditions, J Hazard. Mater. 149 (2007) 482-491.

[28] N.K. Hamadi, X.D. Chen, M.M. Farid, M.G.Q. Lu, Adsorption kinetics for the removal of chromium(VI) from aqueous solution by adsorbents derived from used tyres and sawdust, Chem. Eng. J. 84 (2001) 95-105.

[29] A. Sari and M. Tuzen, Removal of $\mathrm{Cr}(\mathrm{VI})$ From Aqueous Solution by Turkish Vermiculite: Equilibrium, Thermodynamic and Kinetic Studies, Sep. Sci. and Technol. 43 (2008) 3563-3581.

[30] D. Langmuir, Aqueous Environmental Geochemistry, Prentice Hall, NJ, USA, 1997.

[31] A. Sari, M. Tuzen, M. Soylak, Adsorption of $\mathrm{Pb}$ (II) and $\mathrm{Cr}$ (III) from aqueous solution on Celtek clay, J Hazard. Mater. 144 (2007) 41-46.

[32] D. Nityanandi, C.V. Subbhuraam, Kinetics and thermodynamics of adsorption of $\mathrm{Cr}(\mathrm{VI})$ from aqueous solution using puresorbe, J Hazard. Mat. 170 (2009) 876-882.

[33] Y. Liu, H. Li, G.Q. Tan and XH Zhu, $\mathrm{Fe}^{2+}$-modified vermiculite for the removal of chromium (VI) from aqueous solution, Sep. Sci. and Technol. 46 (2011) 290-299.

[34] R.M. Jayabalakrishnan and S. Mahimaraja, Adsorption of hexavalent chromium onto raw vermiculite grades as a function of solution concentration, J. Appl. Sci. Res. 3 (2007) 1262-1266.

[35] K.G. Bhattacharyya and S.S. Gupta, Adsorption of chromium(VI) from water by clays, Ind. Eng. Chem. Res. 45 (2006) 7232-7240. 
[36] B.S. Krishna, D.S.R. Murty and B.S. Jaiprakash, Thermodynamics of chromium(VI) anionic species sorption onto surfactant-modified montmorillonite, J. Colloid Interface Sci. 229 (2000) 230-236.

[37] M. Barros, P.A. Arroyo, E.F. Sousa-Aguiar and C.R.G. Tavares, Thermodynamics of the Exchange Processes between $\mathrm{K}^{+}, \mathrm{Ca}^{2+}$ and $\mathrm{Cr}^{3+}$ in Zeolite NaA. Adsorption 10 (2004) 227-235.

[38] S.S. Baral, S.N. Dasa, P. Rath and G.R. Chaudhury, Chromium(VI) removal by calcined bauxite. Biochem. Eng. J. 34 (2007) 69-75.

[39] Y.C. Sharma, B. Singh, A. Agrawal and C.H. Weng, Removal of chromium by riverbed sand from water and wastewater: Effect of important parameters. J Hazard. Mat. 151 (2008) 789-793.

[40] Yavuz, Orbak and Karatepe, Factors Affecting the Adsorption of Chromium (VI) on Activated Carbon J. Environ. Sci. Health, Part A 41 (2006) 1967-1980.

[41] L. Khezami and R. Capart, Removal of chromium(VI) from aqueous solution by activated carbons: Kinetic and equilibrium studies J. Hazard. Mat. B123 (2005) 223231.

[42] S. Babel and T.A. Kurniawan, Low-cost adsorbents for heavy metals uptake from contaminated water: a review. J Hazard. Mat. B97 (2003) 219-243.

[43] M. Rao, A.V. Parwate and A.G. Bhole, Removal of $\mathrm{Cr}^{6+}$ and $\mathrm{Ni}^{2+}$ from aqueous solution using bagasse and fly ash. Waste Manag. 22 (2002) 821-830.

[44] G. Qian, X. Yang, S. Dong, J. Zhou, Y. Sun, Y. Xu and Q. Liu, Stabilization of chromium-bearing electroplating sludge with MSWI fly ash-based Friedel matrices. J Hazard. Mat. 165 (2009) 955-960.

[45] D.C. Sharma and C.F. Forster, Continuous adsorption and desorption of chromium ions by sphagnum moss peat. Process Biochem. 30 (1995) 293-298.

[46] M. Uysal and A. Irfan, Removal of $\mathrm{Cr}(\mathrm{VI})$ from industrial wastewaters by adsorption. Part I: Determination of optimum conditions. J Hazard. Mat. 149 (2007) 482-491.

[47] S.S. Baral, S.N. Das and P. Rath, Hexavalent chromium removal from aqueous solution by adsorption on treated sawdust. Biochem. Eng. J. 31 (2006) 216-222. 
[48] S. Gupa and B.V. Babu, Utilization of waste product (tamarind seeds) for the removal of $\mathrm{Cr}(\mathrm{VI})$ from aqueous solutions: Equilibrium, kinetics, and regeneration studies. J. Environ. Manag. 90 (2009) 3013-3022.

[49] C. Quintelas, Z.Rocha, B. Silva, B. Fonseca, H. Figueiredo and T. Tavares, Removal of $\mathrm{Cd}(\mathrm{II}), \mathrm{Cr}(\mathrm{VI}), \mathrm{Fe}(\mathrm{III})$ and $\mathrm{Ni}(\mathrm{II})$ from aqueous solutions by an $\mathrm{E}$. coli biofilm supported on kaolin, Chem. Eng. J. 149 (2009) 319-324.

[50] C. Quintelas, B. Fonseca, B. Silva, H. Figueiredo and T. Tavares, Treatment of chromium(VI) solutions in a pilot-scale bioreactor through a biofilm of Arthrobacter viscosus supported on GAC. Bioresour. Technol. 100 (2009) 220-226. 